\title{
Foreign Direct Investment as an Instrument for promoting Economic Development in Bangladesh
}

\author{
Md. Sajedur Rahman ${ }^{1}$, Md. Ali Ahsan² \\ ${ }^{1}$ Lecturer, School of Business, University of Information Technology and Sciences (UITS), Bangladesh \\ ${ }^{2}$ Lecturer, School of Liberal Arts \& Science, University of Information Technology and Sciences (UITS), Bangladesh
}

\begin{abstract}
A healthy financial sector is very much crucial for economic growth, especially for economies like Bangladesh. Because, growth in Bangladesh must come largely from exports and its enterprises must, therefore, be internationally competitive. But unfortunately, Bangladesh has a financial system in which borrowers fail to repay loans, foreclosure is almost unheard of, and the government has to bail out banks. However, the Foreign Direct Investment (FDI), the most powerful weapon for accelerating economic development in Bangladesh. To attain an economic growth rate in the seven to eight percent range, investment has to be increased significantly, Because of declining levels of official development assistance in recent years and inadequate domestic savings, FDI presents opportunities for overcoming domestic resource constraints. The Board of investment (BOI) was created as market mechanism where investors can cut through red-tape associated with foreign trade and business start-ups. FDI basically helps to fill-up the capital gap and shortage of a country. Foreign Direct Investment is one of the vital forces to boost up the economy. In this study paper I would like to draw a current scenario of Foreign Direct Investment in Bangladesh. In this regard I present the most updated data, avoid the uncompleted data and use the best judgment at the time of presenting the data to better knowing the current trend about the Foreign Direct Investment in Bangladesh. The benefits of FDI in terms of physical capital formation, transfer of technology, and know-how are sufficient to justify sustaining these flows. Capital controls are not the answer to a rising flow of FDI. Foreign Direct Investment (FDI) will help the country in further developing infrastructures, creating more employment, developing capacity, enhancing skills of the labour force of the host country through transferring technological knowledge and managerial capability. To ensure that resulting payments liabilities remain within the country's debt-servicing capacity, it is essential to develop an effective nonintrusive reporting and monitoring system the main ingredients of which are presented in the study.
\end{abstract}

Keywords: Foreign Direct Investment status in Bangladesh, Economic growth, Prospects \& problems of FDI, Impact of FDI, Foreign Direct Investment (FDI), Development, Growth benefits.

JEL Classification Code: G11, O24

\section{INTRODUCTION}

$\mathrm{F}$ Tor a resource poor country like Bangladesh Foreign Direct Investment (FDI) can play a crucial role in industrial financing through gathering scattered funds from various global investors in this connection Foreign Direct Investment (FDI) has played a key role in the modernization of the Bangladesh economy for the last 15 years. The total trend in the FDI flows of the developing countries shows an encouraging picture in general terms. More investment is coming from private sectors in the developing countries from the develop one through licensing, franchising, merging, joint venture, contract manufacturing and so forth. Most of the time developing countries become investors among themselves. The situation for LDC's (Least Developed Countries) do not look that bright. Viewed in this context Bangladesh is one of the most populous LDC's needs to make own stock taking of the contemporary global economic situation as far as the FDI flows are concerned. Government of Bangladesh revised its industrial policy of 1991 and offers a number of good facilities and incentives by 1999 to attract FDI. Though the policy has changed, FDI flows to Bangladesh are so far been negligible. Its reform program for outwards looking economics activities have failed to attract FDI a sizeable in comparison with other Asian Countries. Actually success of any policy or organization achievement depends on its ability to establish and maintain a good fit between itself and environment where it will appropriate and on identifying the competitive advantages and exploiting the opportunities in the more efficient manner than that of the competitors. The world economy is in stream of change in order to integrate itself to achieve desire objectives of the economic globalization for the growth and prosperity for the irrespective of region in all parts of the world. Trends in economic policies in both developed and developing countries have been greatly influenced by the globalization that is free market economy and as a matter 
of fact foreign investment and trade labialization have become its prime impulses. The existences of market opportunities, development of communication, information technology and comparative advantages in international level motivate foreign investor in the international business operation. Researchers have marked FDI as an important factor in accelerating economic success and wealth of a country as well as a door in creating jobs, facilitating economy, and creating more competitive environment and contributing productivity to the host country.

In Bangladesh, FDI plays a significant role in GDP acceleration and economic growth (Mottaleb 2007). FDI has a mentionable role in the modernization of the Bangladesh economy for last two decades. It helps the country in building up infrastructure, creating more employment, developing capacity, enhancing skills of the labor force of the host country through transferring technological knowledge and managerial capability, and helping in integrating domestic economy and the global economy. Various positive attributes of Bangladesh is now drawing the attention of the investors from both developed and developing countries. In Bangladesh, it is available to get skilled labor at relatively low wages. Moreover, there is reasonably stable macroeconomic environment. These two important factors can make Bangladesh an alluring destination for foreign investors. Lowest wage rates among the Asian countries, tolerable inflation rate, reasonably stable (except previous year) exchange rate, investment friendly custom regulations and attractive incentive packages make Bangladesh a favorable investment destination. Bangladesh became more open toward FDI policies over the last decades. These above features will certainly maintain the recent advancement in FDI investment in Bangladesh by the foreign investors.

\section{ObJectives of the Study}

- To evaluate the contribution of FDI to the economic development in Bangladesh

- To analyze the impact of FDI inflow on GDP, Export and private investment of Bangladesh

- To measure the status of FDI in Bangladesh

- To identify the problems \& prospects of FDI and try to prescribe some issues for their solution

\section{Methodology of the Study}

The methodology includes an econometric model as well as simple statistical tools such as mean, standard deviation and percentage. This paper is primarily based on secondary information. The relevant secondary data are collected from Statistics Department and Research Department of Bangladesh Bank (Central Bank of Bangladesh), Board of Investment (BOI), Bangladesh, Bangladesh Bank Bulletin, Economic Trend, Bangladesh Economic Review, World Investment Report 2010 published by UNCTAD, websites, journals, books and newspapers etc. By using these data, the study at first has figured out the present condition of FDI of Bangladesh. Thereafter, these data were analyzed to assess the impact of foreign direct investment in the economic development of Bangladesh. Lastly, some policies are suggested for the efficient and useful utilization of FDI by removing existing obstacles to achieve the desired level of economic development for the country.

\section{Literature ReView OF THe Study}

Muhammad Azam (2010) examined the impacts of exports and FDI on economic growth of South Asian countries namely Bangladesh, India, Pakistan and Sri Lanka with simple log linear regression model using secondary data ranging from 1980 to 2009 and found that due to promotion of exports, economic growth of each country would increase. He also found FDI as positively significant at $1 \%$ level of significance for Bangladesh and Pakistan, while for India it's insignificant and in case of Sri Lanka though it is significant but with unexpected negative sign.

Quader, Syed Manzur (2009) applied extreme bounds analysis to the data of the various catalyst variables of FDI inflows in Bangladesh. They found FDI and domestic investment have a positive effect on economic growth.

Abdul Rehman, Orangzab, Ali Raza (2009) conducted an analysis by using the data collected over the period of 1975-2008 and identified the determinants of FDI and its impact on GDP growth in Pakistan through different statistical tests and found positively significant impact of FDI on GDP growth of Pakistan. Furthermore, these results indicate that market size, trade openness / access to international market and quality of labor are the major determinants that have significant affect on the FDI inflow. The study also found no affect of market potential and communication facility on the attraction of FDI inflow in Pakistan.

Mottaleb (2007) studied the determinants of FDI and its effect on economic growth in developing countries. He studied panel data of FDI flows of sixty low-income and lower middle income countries and found that FDI has an important effect on economic growth of third world countries by creating bridge between the gap of domestic savings and investment and familiarizing the up to date technology and management skill from developed countries.

\section{CuRRENT Scenario of FDI In BANGLADESH}

Foreign Direct Investment (FDI) is the acquisition of managerial control by a citizen or corporation of a home nation over a corporation of some other host nation. Corporations that widely engage in FDI are called multinational companies, multinational enterprises, or transnational corporations. FDI traditionally implies export of real capital from home to the host nation, but even when economic investment results from FDI, capital may not be transferred from the home nation to the host 
one. Rather, multinational corporation may acquire/utilize real capital from local (or a third-nation) sources foreign capital" means capital invested in Bangladesh in any industrial undertaking by a citizen of any foreign country or by a company incorporated outside Bangladesh. In the form of foreign exchange, imported machinery and equipment, or in such other form as the government may approve for the purpose of such investment; Bangladesh invites FDI for industrial growth, in particular welcoming establishment of manufacturing firms and service sector enterprises that would sell their products within the country and also export outside it.

Bangladesh is a high performing LDC, which has made significant progress in the 1990s. This represents Bangladesh as an interesting case for FDI destination for the other countries. Bangladesh currently accelerates her GDP growth rate (from 1980s: $3.84 \%$ to $1990 \mathrm{~s}: 4.88 \%$ ), decline in population growth rate (from $2.32 \%$ in early eighties to $1.5 \%$ in late nineties), achieved near full self-sufficiency in foodgrain production through expansion of HYV rice cultivation (17.85 MlnMT in 1991 and 23.07 MlnMT in $2000)$, performed high growth of export sector (12.98\% per annum during 1990s), made subsequent improvement in human development index (Infant mortality rate declined from 153 per thousand live births in 1975 to 94 in 1990, and to 66 in 2000), achieved considerable success in mainstreaming of women by achieving gender parity in primary education, and almost removed gender gap in secondary education, demonstrated significant progress towards a viable democratic structure - change of government through three successive national elections. Share of private investment in GDP increased from $10.3 \%$ in FY91 to $16.5 \%$ in FY03. However, there is little room of exercise if the country desires to accomplish her targets as mentioned in the Millennium Development Goal (MDG) and MTMF (Medium-Term Macroeconomic Framework) of its Poverty Reduction Strategy Paper (PRSP) - the implementation framework of the National Strategy for Economic Growth, Poverty Reduction and Social Development. For sustained development with equity, Bangladesh desperately needs both domestic and foreign direct investment to boost the present trend of growth. The FDI mentioned US\$ 768.7 million in FY 2007-08. During FY 2008-09; the actual FDI recorded US\$ 960.6 million, which was higher than the previous fiscal year. The key feature of this increasing flow of investment during FY 2008-09 was a favorable investment environment and political stability. In FY 2009-10(up to Dec"10) the actual FDI recorded US\$ 342.2 which is lower than the previous fiscal year because of world economic recession. Table 1 presents the recent trend in FDI inflow in Bangladesh:

Table 01: Recent Trend in FDI Inflow in Bangladesh. (US\$ Millions)

\begin{tabular}{|c|c|c|c|c|c|c|c|c|}
\hline FY & FY & FY & FY & FY & FY & FY & FY & FY \\
2001 & 2002 & 2003 & 2004 & 2005 & 2006 & 2007 & 2008 & 2009 \\
-02 & -03 & -04 & -05 & -06 & -07 & -08 & -09 & $-10^{*}$ \\
\hline 393.8 & 379.2 & 284.1 & 803.8 & 744.6 & 792.8 & 768.7 & 960.6 & $342.2^{*}$ \\
\hline
\end{tabular}

Source: Enterprise Survey, Bangladesh Bank *July-Dec 2009-10, *Estimated

The Table shows that FDI inflow to Bangladesh was $\$ 1086$ million in 2008, the highest so far in its history, but it fell significantly thereafter, falling by 34.1 percent to \$716 million in 2009.

Table 02: Foreign Direct Investment Inflow

\begin{tabular}{|c|c|c|c|c|c|c|c|}
\hline Countries & \multicolumn{4}{|c|}{$\begin{array}{c}\text { FDI Inflows } \\
\text { (Million US\$) }\end{array}$} & \multicolumn{3}{c|}{$\begin{array}{c}\text { FDI Stock } \\
\text { Million US\$) }\end{array}$} \\
\cline { 2 - 9 } & $\begin{array}{c}\text { 1995-2005 } \\
\text { (Annual } \\
\text { Avg.) }\end{array}$ & 2009 & 2010 & 2011 & 1995 & 2009 & 2010 \\
\hline Bangladesh & 427 & 1086 & 716 & $>1$ billion & 600 & 4816 & 5139 \\
\hline India & 4137 & 40148 & 34613 & - & 5641 & 123294 & 163959 \\
\hline Pakistan & 732 & 5438 & 2387 & - & 5408 & 16473 & 17789 \\
\hline Vietnam & 1657 & 8050 & 4500 & - & 7150 & 48325 & 52825 \\
\hline
\end{tabular}

Source: UNCTAD, World Investment Report, 2012

The decline occurred across all three sectors of FDI primary, manufacturing and services, and most FDI components - equity investment, intra-company loans or reinvested earnings - contracted. In the first half of 2010, the global FDI witnessed a modest recovery, sparking some cautious optimism for FDI prospects in the short term and for a full recovery further on, but these prospects are fraught with risks and uncertainties, including the fragility of global economic recovery. (UNCTAD, op. cit)

The table 3 shows that United Kingdom has gained the top most position among the top 10 investing countries in Bangladesh during 2006-2010 in investing in various sectors of economy. Out of total FDI inflows from the top 10 investing countries during this period, $17.4 \%$ was from United Kingdom, 13\% from USA, 8\% from Egypt, $7.7 \%$ from South Korea, 6.4\% from Netherlands, $6.2 \%$ from Singapore, 5.6\% from Hong Kong, 5.2\% UAE, 4.8\% from Japan, 3.5\% from Malaysia, 3.2\% from Australia, $2.1 \%$ from Denmark, $2.1 \%$ from Switzerland.

Table 03: FDI Inflows (in million US\$) by Countries during 2006-2010.

\begin{tabular}{|l|c|c|c|c|c|}
\hline Country & $\mathbf{2 0 0 6}$ & $\mathbf{2 0 0 7}$ & $\mathbf{2 0 0 8}$ & $\mathbf{2 0 0 9}$ & $\mathbf{2 0 1 0}$ \\
\hline Australia & 0 & 0 & 0 & 0.22 & 13.95 \\
\hline China & 0.92 & 0.48 & 4.5 & 3.24 & 8.66 \\
\hline Denmark & 15.38 & 8.99 & 1.91 & 9.09 & 5.91 \\
\hline Egypt & 105.36 & 75.17 & 373.4 & 72.71 & 3.01 \\
\hline Hong Kong & 47.43 & 55.45 & 39.85 & 75.6 & 63.84 \\
\hline India & 6.09 & 1.67 & 11.29 & 7.99 & 43.19 \\
\hline Japan & 22.79 & 36.61 & 57.15 & 17.47 & 21.79 \\
\hline Malaysia & 44.46 & 19.54 & 70.72 & 43.84 & 7.45 \\
\hline Netherlands & 13 & 18.67 & 31.67 & 49.62 & 64.92 \\
\hline
\end{tabular}


Asian Business Review, Volume 3, Number 2/2013 (Issue 6)

ISSN 2304-2613 (Print); ISSN 2305-8730 (Online)

\begin{tabular}{|l|c|c|c|c|c|}
\hline Norway & 82.95 & 25.68 & 33.47 & 45.63 & 39.16 \\
\hline Pakistan & 5.14 & 3.49 & 12.51 & 30.14 & 18.88 \\
\hline Saudi Arabia & 0.52 & 1.73 & 2.66 & 2.62 & 11.91 \\
\hline Singapore & 35.89 & 10.68 & 32.28 & 19.12 & 317.19 \\
\hline South Korea & 53.86 & 27.68 & 44.64 & 46 & 40 \\
\hline Sri Lanka & 2.63 & 3.55 & 7.19 & 7.37 & 8.85 \\
\hline Switzerland & 2.8 & 13.39 & 69.25 & 29.06 & 5.89 \\
\hline Taiwan & 2.36 & 0.17 & 1.96 & 11.1 & 7.59 \\
\hline UAE & 88.02 & 83.27 & 102.2 & 67.08 & 24.5 \\
\hline U.S.A & 175.72 & 120.36 & 40.92 & 42.89 & 56.95 \\
\hline U.K & 70.47 & 142.55 & 130.57 & 88.08 & 105.68 \\
\hline A.D.B & 0 & 0 & 0 & 0 & 0 \\
\hline I.F.C & 0 & 0 & 0 & 0 & 0 \\
\hline Others & 16.69 & 17.23 & 18.17 & 31.29 & 44 \\
\hline
\end{tabular}

Source: Board of Investment, Bangladesh.

Sector-wise analysis of FDI reveals the fact that a shift has been made by the foreign investors in their investment in Bangladesh (Annex Table-3.4). The table shows the trend of FDI towards power and energy, manufacturing and telecommunications, whereas the neglected sectors were agricultural, Services and trade and commerce. In 2005, the main focus of investment was in the manufacturing sector. The success in textiles through the ready-made garments (RMG) industry was a vital part of this investment.

In the table 4 and 5 it is clearly shown that the percentage of investment in various sectors has changed quite a lot. The percentage of telecommunication investment was $2 \%$ in $2006-2000$ was only $2 \%$, which increases to $21 \%$ during 2001-2005 and finally it topped to $43 \%$ during 2006-2010. On the other hand, the portion of investment in the gas \& petroleum sector has declined gradually during the year of 1996 to 2010 . It was $28 \%$ in 2006-2000, $18 \%$ in $2001-2005$ and only $13 \%$ in $2006-2010$. It is also a matter of great concern that the investment in energy sector has decreased from $12 \%$ to only $3 \%$, which is very alarming. The government should take a close look in this matter and take necessary steps to identify the causing factors and to rectify those to improve our present energy sector conditions.

Table 04: FDI Inflows (in million US\$) by Sectors in Bangladesh during 2006-2010.

\begin{tabular}{|l|c|c|c|c|c|}
\hline Sectors & $\mathbf{2 0 0 6}$ & $\mathbf{2 0 0 7}$ & $\mathbf{2 0 0 8}$ & $\mathbf{2 0 0 9}$ & $\mathbf{2 0 1 0}$ \\
\hline Agriculture \& Fishing & 1.3 & 7.3 & 14.4 & 11.8 & 13.6 \\
\hline Power & 21.1 & 25.8 & 27.8 & 30.9 & 38.5 \\
\hline Gas \& Petroleum & 187.1 & 190.2 & 73.3 & 20.3 & 53.6 \\
\hline Textiles \& Wearing & 70.1 & 102.3 & 126.4 & 134.0 & 145.2 \\
\hline Chemicals \& Pharmaceuticals & 5.2 & 4.2 & 3.9 & 10.4 & 6.3 \\
\hline Metal \& Machinery Products & 0.0 & 0.0 & 0.0 & 1.3 & 3.1 \\
\hline Leather \& Leather Products & 0.0 & 1.5 & 1.6 & 7.2 & 10.5 \\
\hline Banking & 117.7 & 80.0 & 141.8 & 142.6 & 163.1 \\
\hline Insurance & 6.4 & 7.3 & 4.6 & 10.4 & 16.7 \\
\hline
\end{tabular}

\begin{tabular}{|l|c|c|c|c|c|}
\hline Telecommunication & 346.5 & 201.9 & 641.4 & 250.1 & 359.8 \\
\hline Coction
\end{tabular}

\begin{tabular}{|l|c|c|c|c|c|}
\hline Computer Software \& IT & 0.2 & 0.0 & 0.4 & 1.8 & 5.0 \\
\hline
\end{tabular}

Source: Survey Report, Statistics Department of Bangladesh Bank and Foreign Direct Investment in Bangladesh (1971-2010), Board of Investment.

Figure 3.3.1 reveals that despite the initial increase and steady continuation, FDI inflows in Non-EPZ areas was in declining trend during the period of 2001-2003. In 2004 it increased to 800 million USD and this trend continued up to 2005.The FDI inflows in Non-EPZ areas in 2010 recorded to USD 795.15 million which is 87 percent of total inflows whereas in the beginning of this period (in 1996) it was USD 189.3 million which is 82 percent of total inflows. In the EPZ areas, the FDI inflows were always in a steady direction.

Table 05: FDI Inflows by Areas. (in million US\$)

\begin{tabular}{|c|c|c|c|}
\hline Year & \multicolumn{3}{|c|}{ Area } \\
\hline & EPZ & Non-EPZ & Total \\
\hline 1996 & 42.31 & 189.3 & 231.61 \\
\hline 1997 & 69.25 & 506.04 & 575.29 \\
\hline 1998 & 88.31 & 488.15 & 576.46 \\
\hline 1999 & 154.43 & 154.69 & 309.12 \\
\hline 2000 & 81.2 & 497.44 & 578.64 \\
\hline 2001 & 56.06 & 298.41 & 354.47 \\
\hline 2002 & 87.53 & 247.94 & 335.47 \\
\hline 2003 & 59.31 & 290.94 & 350.25 \\
\hline 2004 & 42.68 & 417.72 & 460.4 \\
\hline 2005 & 110.82 & 734.44 & 845.26 \\
\hline 2006 & 71.03 & 721.44 & 792.48 \\
\hline 2007 & 105.44 & 560.93 & 666.36 \\
\hline 2008 & 118.55 & 967.76 & 1086.31 \\
\hline 2009 & 141.88 & 558.28 & 700.16 \\
\hline 2010 & 118.17 & 795.15 & 913.32 \\
\hline
\end{tabular}

FDI in Bangladesh consists of three components: Equity capital, Reinvested Earnings and Intra-company loans. These components have fluctuated considerably in the last two decades. In the early year of 1996, the total FDI inflow was only 210 million USD where reinvested earnings were the bigger portion. This trend continued up to 1998. Then there is a sudden decline in terms of total inflow as well as component wise inflow of FDI. Beside a slight increase in 2000, this declining trend continues up to 2003. After then total inflow continues to rise with some ups and downs. The portion of equity capital continues to have a bigger part in the total FDI inflows. In 2008 the total inflows was 1100 million USD which is the highest ever.

Table 06: FDI Inflows by Components (in million US\$)

\begin{tabular}{|c|c|c|c|c|}
\hline Year & $\begin{array}{c}\text { Equity } \\
\text { Capital }\end{array}$ & $\begin{array}{c}\text { Reinvested } \\
\text { earnings }\end{array}$ & $\begin{array}{c}\text { Intra- } \\
\text { company } \\
\text { Loans }\end{array}$ & $\begin{array}{c}\text { Total } \\
\text { Inflows }\end{array}$ \\
\hline 1996 & 69.63 & 121.65 & 40.33 & 231.61 \\
\hline
\end{tabular}


Asian Business Review, Volume 3, Number 2/2013 (Issue 6)

ISSN 2304-2613 (Print); ISSN 2305-8730 (Online)

\begin{tabular}{|c|c|c|c|c|}
\hline 1997 & 332.06 & 163.45 & 79.78 & 575.29 \\
\hline 1998 & 280.51 & 189.88 & 105.07 & 576.46 \\
\hline 1999 & 137.47 & 76.23 & 95.42 & 309.12 \\
\hline 2000 & 350.18 & 77.77 & 150.69 & 578.64 \\
\hline 2001 & 233.78 & 65.01 & 55.68 & 354.47 \\
\hline 2002 & 133.81 & 116.82 & 84.84 & 335.47 \\
\hline 2003 & 156.14 & 170.13 & 23.98 & 350.25 \\
\hline 2004 & 155.89 & 239.79 & 64.72 & 460.4 \\
\hline 2005 & 425.59 & 247.48 & 172.19 & 845.26 \\
\hline 2006 & 503.65 & 264.74 & 24.09 & 792.48 \\
\hline 2007 & 401.61 & 213.24 & 51.51 & 666.36 \\
\hline 2008 & 809.25 & 245.73 & 31.33 & 1086.31 \\
\hline 2009 & 218.55 & 364.94 & 116.67 & 700.16 \\
\hline 2010 & 519.98 & 364.62 & 28.72 & 913.32 \\
\hline
\end{tabular}

From table 7 , it is found that the overall scenario of the trend of the private investment in Bangladesh is increasing.

Table 07: Private Investment Statistics

\begin{tabular}{|c|c|c|c|c|c|c|c|}
\hline Year & $\begin{array}{c}\text { Proposed } \\
\text { Local } \\
\text { Investment }\end{array}$ & $\begin{array}{c}\text { Proposed } \\
\text { Foreign } \\
\text { Investment }\end{array}$ & $\begin{array}{c}\text { Total } \\
\text { Proposed } \\
\text { Investment }\end{array}$ & $\begin{array}{c}\text { Growth } \\
\%\end{array}$ \\
\cline { 2 - 6 } Project & BDT & Project & BDT & Projec & BDT & \\
\hline $\begin{array}{r}2005- \\
2006\end{array}$ & 1754 & 18370 & 135 & 24986 & 1889 & 43356 & 124.62 \\
\hline $\begin{array}{c}2006- \\
2007\end{array}$ & 1930 & 19658 & 191 & 11925 & 2121 & 31583 & -27.15 \\
\hline $\begin{array}{c}2007- \\
2008\end{array}$ & 1615 & 19553 & 143 & 5433 & 1758 & 24986 & -20.89 \\
\hline $\begin{array}{c}2008- \\
2009\end{array}$ & 1336 & 17117 & 132 & 14749 & 1468 & 31867 & 27.54 \\
\hline $\begin{array}{c}2009- \\
2010\end{array}$ & 1470 & 27414 & 160 & 6261 & 1630 & 33678 & 5.67 \\
\hline $\begin{array}{c}2010- \\
2011\end{array}$ & 1298 & 39976 & 148 & 26935 & 1446 & 66912 & 98.71 \\
\hline $011-201$ & 1604 & 497079 & 209 & 338910 & 1813 & 835989 & 212 \\
\hline
\end{tabular}

In the year 2009-10 (February), there were 89 new foreign and joint venture investment projects registered to BOI which amount to $\$ 590 \mathrm{~m}$. The projects were invested to mainly in the service, engineering, clothing and agricultural sectors.

Table 08: Country wise foreign and joint venture investment during 2009-2010*

\begin{tabular}{|l|c|c|}
\hline Country & $\begin{array}{c}\text { No. of } \\
\text { Projects }\end{array}$ & $\begin{array}{c}\text { Proposed } \\
\text { Investment (US\$ m) }\end{array}$ \\
\hline Saudi Arabia & 3 & 478.652 \\
\hline Australia & 4 & 2.036 \\
\hline USA & 5 & 2.990 \\
\hline Finland & 2 & 3.023 \\
\hline India & 9 & 8.451 \\
\hline South Korea & 12 & 33.768 \\
\hline Malaysia & 3 & 3.056 \\
\hline Netherlands & 5 & 8.544 \\
\hline China & 12 & 21.000 \\
\hline
\end{tabular}

\begin{tabular}{|l|c|c|}
\hline United Kingdom & 5 & 3.507 \\
\hline Pakistan & 2 & 0.990 \\
\hline Japan & 8 & 2.624 \\
\hline Denmark & 1 & 1.217 \\
\hline Sri Lanka & 2 & 0.646 \\
\hline Canada & 2 & 1.017 \\
\hline Taiwan & 1 & 0.502 \\
\hline Singapore & 4 & 1.929 \\
\hline Turkey & 1 & 0.150 \\
\hline Greece & 1 & 0.156 \\
\hline Italy & 2 & 1.039 \\
\hline Hong Kong & 5 & 14.805 \\
\hline Total & 89 & 590.102 \\
\hline
\end{tabular}

Source: Bangladesh, Ministry of Finance as of February, 2010

\section{Factors afFecting Foreign DiRect INVESTMENT}

Although Bangladesh is trying to be as friendly as possible to FDI, she is facing some problems regarding investment from foreign sector. The FDI friendly policies of the government and a culture of hospitality to foreigners are very much positive to welcome FDI in Bangladesh. But it is a matter of concern that FDI records in the country in terms of the number of projects implemented as compared to those officially registered is frustrating. Only 72 FDI projects went into production in end of 1999 and 27 were in process of implementation of the 365 FDI projects registered during the year of 1996 1998, while the remaining 266 projects languished only as the file-cases. The problems that have restricted FDI potentials in the country are as follows:

- Bureaucratic interference

- Irregularities in processing papers

- Overlapping administrative procedures

- Absence of a transparent system of formalities

Continuity and prevent timely implementation of strategic, procedural, and even routine duties

- Frequent power failures

- Poor infrastructure support

- Labor unrest

- Political unrest

- Lack of professional personnel

- lack of commitment on the part of local investors

- Unexpected delays in selecting projects in studying feasibility

- Frequent changes in policies on import duties for raw materials, machinery and equipment etc.

Because Foreign Direct Investment can significantly affect a country's economy, the most influential factors are Inflation, National income, Government restriction, and Exchange rates.

Impact of Inflation: If a country's inflation rate increases relative to the countries with which it invests, its capital 
account would be expected to decrease, other things being equal. Consumer and corporations in that country will most likely purchase more goods or invest more in overseas (due to high local inflation), while the country's exports to other countries \& flow of investment from foreign will decline.

Impact of National Income: If a country's income level (national income) increases by a higher percentage than those of other countries, its capital account is expected to decrease, other things being equal. As the real income level (adjusted for inflation) raises does consumption of goods. A percentage of that increase in consumption will most likely reflect an increased demand for foreign investment.

Impact of Government Restrictions: A country's Government can prevent or discourage investment from other countries. By imposing such restrictions, the Government disrupts investment flows. Among the most commonly used investment restriction are bureaucratic tangles, projection of intellectual property right and fiscal policy changes. In addition to these, a Government can reduce its country's investment by enforcing laws, or a maximum limit that can be invested.

Impact of Exchange Rates: Each country's currency is valued in terms of other currencies through the use of exchanges rates, so that currencies can be exchanged to facilitate international transaction. The values of most currencies can fluctuate over time because of market and government forces. If a country's currency begins to rise in value against other currencies, its capital account balance should decrease, other things being equal. As the currency strengthens, Investment by that country will become more expensive than the receiving countries.

Prospects of FDI: Bangladesh has been promoting FDI for decades with the most liberal investment policy and incentive regime in South Asia. The Foreign Private Investment (Promotion and Protection) Act, 1980, ensures equal treatment for local and foreign Investors. This act also provides legal protection to foreign investment in Bangladesh against nationalization and expropriation. It also gives the guarantee of repatriation of capital and dividend.

Bangladesh has achieved a consistent GDP growth of over $5 \%$ in the last decade and never experienced a negative growth. Even Bangladesh sustained growth of over 5\% during the recent global economic crisis. In 2009 Bangladesh achieved a 5.9\% GDP growth. Various necessary steps like generation of huge number of SMEs, success in micro credit and NGO activities, rapid spread of telecommunications services, record level of foreign remittances, acceleration of export earnings are taking the economy at a higher level of growth. Its investment friendly climate offers generous and attractive packages of incentives for foreign investors like 100\% ownership, tax and duty exemptions and others. Actually, Bangladesh has gained a higher ranking than many developing countries in terms of incentive package. A lot of additional fiscal incentives are offered to export oriented industries. The government has created Export processing zones (EPZs) to attract private investment. The government targets foreign investors to invest in EPZ.

The vision is that the unique opportunities in energy and power, infrastructures, manufacturing and knowledgebased sectors will attract substantial investment. Bangladesh has become a least cost producer in the world with various positive factors like industrious lowcost workforce, strategic location, regional connectivity and worldwide access, strong local market and growth, low cost of energy, proven export competitiveness, competitive incentives, export and economic zones, positive investment climate. Bangladesh is ranked 119th position globally and 4th in the SAARC region in the Ease of Doing Business Ranking by World Bank and IFC report entitled "Doing Business in 2010".

\section{Facilities Should be Provided by the GOVERNMENT OF BANGLADESH FOR ATTRACTING FDI}

The world has seen a spectacular wave of global corporate activity particularly during the second half of the last decade. This has been facilitated by advances made in the information technology. This trend, strengthened with the direction toward border less Economies, is drawing more and more TNCs (Trans National Corporation) into the global operation. FDI is no longer only a strategic option of corporations; it also plays a key role in the national economic development strategies. Various countries are attempting to attract foreign investors through a variety of measures, i.e. liberalization of investment environment, fiscal reforms and a package of incentive offers. FDI can transform a country's economic scenario within shortest possible time. It is not merely access to fund, but also provide transfer of technical know-how and management expertise. It is also a stabilizing factor in any economy, because once TNCs have made an asset-based direct investment, they cannot simply pull out overnight like in the case of portfolio investment. Normally the benefits accruable from FDI are inclusive of-

- Transfer of technology to individual firms and technological spill-over to the wider economy,

- Increased productive efficiency due to competition from multinational subsidiaries

- Improvement in the quality of the factors of production including management in other firms, not just the host firm,

- Benefits to the balance of payments through inflow of investment funds,

- Increase in exports

- Increase in savings and investment and

- Faster growth and employment.

- 5 to 7 years corporate tax holiday for selected sectors. 
- Private power companies enjoy corporate income tax exemption for a period of 15 years.

- Tax exemption on royalties, technical know-how and technical assistance fees and facilities for their repatriation.

- Tax exemption on foreign loans regarding interest.

- Tax exemptions on capital gains from transfer of shares by the investing company.

- Remittances of up to $50 \%$ of salaries of the foreigners employed in Bangladesh and facilities for repatriation of their savings and retirement benefits at the time of their return.

- No restrictions on issuance of work permits to project related foreign nationals and employees.

- Facilities for repatriation of invested capital, profits and dividends.

- Provision of transfer of shares held by foreign shareholders to local investors.

- Reinvestment of remittable dividends would be treated as new investment.

- An investor can wind up on investment either through a decision of the AGM. Once a foreign investor completes the related formalities to exit the country, he or she can repatriate the sales proceeds after securing proper authorization from the Central bank.

Thus, foreign direct investment is viewed as a major stimulus to economic growth in developing countries. Its ability to deal with two major obstacles, namely, shortages of financial resources and technology and skills, has made it the centre of attention for policymakers in low-income countries in particular.

\section{CONCLUSION}

Despite the presence of natural calamities like floods and political feud between the country's two major political parties, the investment situation of Bangladesh remains attractive to foreign investors. One of the major causes of such attraction is high return to investment ratio. According to business analysis Bangladesh remains as one of Asia's most attractive business place where return to investment is in many cases 3 to 4 times higher than many other South Asian or South East Asian countries in specific sectors. Bangladesh with its widely available English educated but cheap manpower, operational and close to land sea ports and liberal economic policies is believed by experts to attract more foreign investment, specially from middle eastern nations, in the post 9/11 world scenario. The government initiated fiscal reforms, undertook ambitious scheme to improve general literacy in general and female literacy in particular, started creating conducive environment for investment and above all established rule of law in the country. Improvement in various social development indicators during the last ten years is the testimony of all these efforts. Beyond these steps some other incentives are essential for accelerating FDI. Moreover government as well as oppositions should adopt national policy on investment under natural discussion, so that whoever comes to power will not reject the policy of previous ruling party and pay high positive attentions to the views of the prospective investors.

\section{References}

[1] ADB (2010): Quarterly Economic Update, Bangladesh, September.-2010, Dhaka.

[2] Aitken, Brian J. and Harrison, Ann E., 1999, ‘Do Domestic Firms Benefit from Direct Foreign Investment? Evidence from Venezuela', American Economic Review, Vol. 89, pp.605-18.

[3] Alfaro, L., Chanda, Kalemli-Ozcan, S., and Sayek, S., 2006, 'How do foreign direct investments promote economic growth? Exploring the effects of financial markets on linkages', NBER Working Paper Series 12522: 1-58.

[4] Athukorala P. A W., 2003, 'The Impact of Foreign Direct Investment for Economic Growth: A Case Study in Sri Lanka' 9th International conference on Sri Lanka Studies, 28th- 30th November 2003, Matara, Sri Lanka, Full Paper Number 092.

[5] Agosin, Manuel R. and Mayer, Ricardo, 2000, 'Foreign Investment in Developing Countries: Does It Crowd In Domestic Investment?' UNCTAD Discussion Paper 146, Geneva.

[6] Balamurali, N. and Bogahawatte, C., 2004, 'Foreign Direct Investment and Economic Growth in Sri Lanka, Sri Lankan Journal of Agricultural Economics', Vol. 6, No. 1, pp. 37-50.

[7] BB: Bangladesh Bank Annual Report, (Various Issues), Bangladesh Bank, Dhaka.

[8] BB: Economic Trend, (Various Issues), Bangladesh Bank, Dhaka.

[9] BBS (1993): Twenty Years of National Accounting of Bangladesh, Bangladesh Bureau of Statistics, Dhaka.

[10] GOB: Economic Review, (Various Issues), Ministry of Finance, Dhaka.

[11] Misztal, Piotr, 2010, 'Foreign Direct Investments, As a Factor for Economic Growth in Romania' Journal of Advanced Studies in Finance, Vol. 1, Issue. 1, pp. 72-82.

[12] Quader, Syed Manzur, 2009, 'Foreign Direct Investment in Bangladesh: An Empirical Analysis on its Determinants and Impacts', Retrieved from http://mpra.ub.unimuenchen.de/26134/MPRA Paper No.26134.

[13] Rehman Abdul, Orangzab, Raza Ali, 2011, 'Determinants of Foreign Direct investment and its impact on GDP Growth in Pakistan', Interdisciplinary Journal of Contemporary Research in Business Vol. 2, Issue. 9, pp. 198-205.

[14] Rahman, Atiur (2006) "Measures to make FDI work", The Daily Star, February 16, 2006.

[15] Rothgeb, John M., Jr, 1984, 'The Effects of Foreign Investment On Overall And Sectoral Growth In Third World States', Journal of Peace Research, Vol. 21, No. 1, pp. 5-15.

[16] Teanravisitsagool, Pattama, 1998, 'Trade-off between Foreign and Domestic Investment: Theoretical Analysis and Empirical Investigation for the Case of Thailand', Department of Economics, Carleton University.

[17] UNCTAD (2011): World Investment Report, United Nations, New York. 
Asian Business Review, Volume 3, Number 2/2013 (Issue 6)

ISSN 2304-2613 (Print); ISSN 2305-8730 (Online)

[18] UNCTAD (1999): Foreign Portfolio Investment (FPI) and foreign Direct Investment (FDI): Characteristics, Similarities, complementarities and Differences, Policy Implications and Development Impact, United Nations, New York.

[19] Xiaohui L., Chang S. and P. Sinclair, 2009, 'Trade, Foreign Direct Investment and Economic Growth in Asian Economies', Applied Economics, Vol. 41, pp. 1603 - 1612

[20] www.boi.gov.bd, retrieved on 31 May 2013

[21] www.bangladesh-bank.org, retrieved on 27 May 2013

[22] www.mof.gov.bd, retrieved on 27 May 2013

[23] www.tcb.gov.bd, retrieved on 25 May 2013

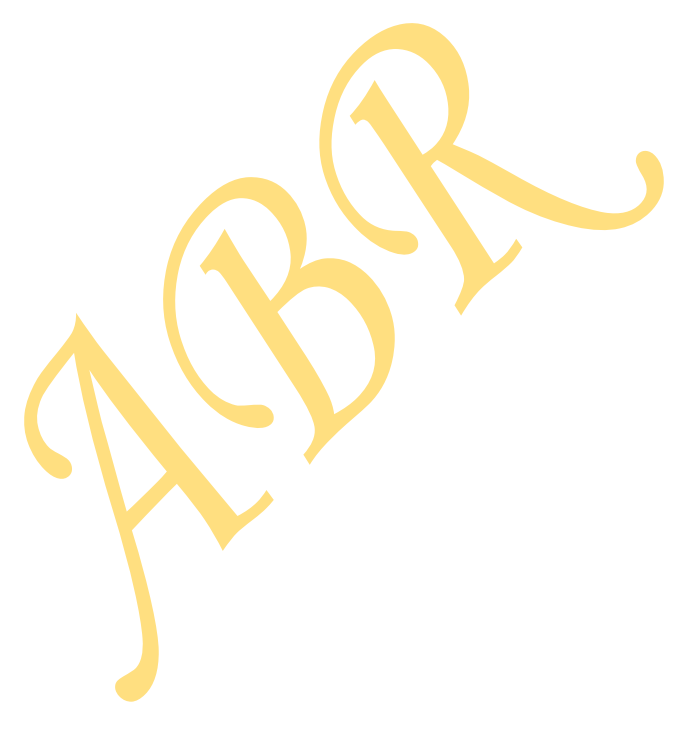

